\title{
POLÍTICAS PÚBLICAS E ESTADO: O PLANO REAL
}

Marcus lanoni

O objetivo do artigo é demonstrar a efetividade do Plano Real na indução do processo de reconstrução da estrutura de poder do Estado brasileiro. O argumento explicativo é que o Plano Real resolve, embora não a ponto de solucionar, questões-chave e interdependentes da crise multidimensional então existente no país. O Plano Real resolve problemas relacionados: 1) à nova inserção internacional orientada para o mercado dos setores público e privado da economia brasileira; 2) à repactuação sociopolítica, que deixa para trás mais de uma década de crise de hegemonia, aberta pela ruptura da aliança desenvolvimentista; 3 ) à ordem político-institucional; 4) e à esfera ideológica, por assegurar, de imediato, e induzir, ao longo do tempo, a um ambiente nacional muito mais propício à expansão da cultura e da agenda liberais, sob diferentes matizes, entre os agentes de mercado, elites políticas e atores sociais.

Importou para essa ampla mudança uma ação política de grande envergadura, síntese de vontade política, ideias (econômicas e políticas), conjuntura histórica e determinações estruturais. Para evidenciar o caráter multidimensio- 
nal do Plano Real, o artigo expõe os conteúdos históricoestrutural, sociopolítico, ideológico e político-institucional da crise e alguns de seus desenvolvimentos e conjunturas, sobretudo o período corrido desde a ascensão interina de Itamar Franco à Presidência da República, em outubro de 1992, durante a tramitação do impeachment de Fernando Collor de Mello até a posse e início de mandato presidencial de Fernando Henrique Cardoso (doravante FHC). Este, em princípio como Ministro da Fazenda, depois como candidato à Presidência e no exercício do cargo de Presidente da República, atuando como condottiere, lidera, vinculado a condições econômicas, sociais e políticas específicas, a mobilização dos recursos de poder que suportaram a formulação e implementação do Plano Real. Tal feito opera uma mudança histórica na crise multidimensional em que o país se encontrava e que tinha em seu centro, num olhar macroestrutural, a derrocada do padrão de financiamento

144 do modelo nacional-desenvolvimentista e as transformações nas conexões do Estado e da economia brasileiros com os mercados mundiais e com o sistema internacional no contexto da globalização. ${ }^{1}$

A análise do processo do Plano Real (seu ingresso na agenda política, sua formulação e alguns efeitos amplos de sua implementação), inserida no contexto macroestrutural, sociopolítico e político-institucional no qual interagiam, naquela conjuntura, atores e ideias, traz vantagens. Mostra que a explicação predominante na literatura de ciência política brasileira de então sobre a crise do Estado não dava e não deu conta do que efetivamente estava acontecendo no país, por se basear demasiadamente numa visão de autonomia da esfera político-institucional em relação à sociedade e à economia. Naquela ocasião, tal

\footnotetext{
${ }^{1} \mathrm{O}$ artigo sintetiza, com alguma atualização, a tese de doutorado "O real no poder: crise de estado, estabilização econômica e reformas estruturais no Brasil”, defendida na PUC-SP em 1997.
} 
reducionismo expressou-se na supervalorização da reforma política como caminho necessário para a superação dos grandes dilemas nacionais, que, na verdade, extrapolavam, embora também englobassem, as instituições políticas. $\mathrm{O}$ processo do Plano Real operou uma virada profunda na conjuntura sem que nenhuma medida de reforma política precedesse a realização da estabilização monetária. ${ }^{2} \mathrm{O}$ enfoque adotado também dialoga com análises pós-Plano Real da literatura de ciência política que concebem essa policy em chaves teóricas centradas em ideias e nas interações entre atores e instituições. Embora relevantes, ideias e instituições inserem-se num universo explicativo mais amplo que aqui será exposto. ${ }^{3}$ A análise política do processo de emergência e efetividade do Plano Real requer uma abordagem abrangente, que incorpore perspectivas da sociologia política e da ciência política neoinstitucionalista, para conectar duas dimensões distintas: Estado e regime. ${ }^{4}$

O recurso metodológico de analisar amplamente a conjuntura de emersão do Plano Real não subentende reduzir o passado ao presente ou deduzir o passado partindo do presente. Tal como o presente possui incertezas e um leque de resultados políticos possíveis, uns mais outros menos prováveis de ocorrerem, o passado, que então foi presente, estava sob tendências diversas, inclusive pelas trajetórias anteriormente percorridas. ${ }^{5}$ Se certas tendências prevaleceram com consistência, é fundamental explicá-las com um

\footnotetext{
${ }^{2}$ A primeira medida importante de reforma política aprovada então pelo Congresso Nacional aconteceu em 1997, com a Emenda Constitucional $n^{\circ} 16$, que introduziu a reeleição. A efetividade do Plano Real trouxe uma mudança políticoinstitucional de impacto, e não o inverso.

${ }^{3}$ Pio (2001) centra sua análise do Plano Real nas ideias econômicas e nas condições político-institucionais. Borba (2002) faz uma revisão da literatura explicativa do Plano Real.

${ }^{4}$ Para uma crítica às ciências sociais contemporâneas, consultar Brandão (1998).

${ }^{5}$ O neoinstitucionalismo histórico traz importantes contribuições para a análise.
} 
método de análise comprometido, o quanto possível, com a densa complexidade da situação. Isso requer identificar as forças políticas, processos e instituições em interação no contexto democrático de incerteza relativa a ser investigado. Evocar a incerteza relativa significa considerar que as ações e lutas políticas envolvendo Estado e sociedade se inscrevem em marcos estruturais e conjunturais que delimitam tanto o campo contingente das interações políticas entre os atores como um conjunto de variáveis relacionadas às políticas públicas. Essa abordagem é especialmente importante quando se analisa uma política pública de imensa envergadura, como é o Plano Real. ${ }^{6}$

Procura-se evitar dois reducionismos: o hiperfuncionalismo das abordagens, nas quais a política é um epifenômeno de estruturas econômicas e sociais, e o hiperinstitucionalismo, particularmente aquele que, naquela conjuntura, considerava serem os problemas do país de crise de 146 governabilidade, cuja superação, segundo seus teóricos, dependia da reforma política, sobretudo da adoção do parlamentarismo. A análise procura mostrar que a crise multidimensional foi superada muito em função da interação entre a virtù da liderança política de FHC (incluindo sua equipe econômica e a coalizão partidária liberal articulada) e as características gerais de uma conjuntura da crise estrutural, nela encerrada a fortuna. Não ocorreu, por um lado, determinismo economicista no processo político, nem, por outro, transformações de causalidade voluntarista e indeterminista na dinâmica da crise estrutural. A abordagem adotada é, portanto, pluricausal. Envolve a inter-relação de elementos macroestruturais, sociopolíticos, político-institucionais e de ação política individual e coletiva. A leitura que este texto faz da crise de então, da

\footnotetext{
${ }^{6}$ Sobre aspectos teóricos da pesquisa em políticas públicas, consultar Reis (2003).
} 
conjuntura de emergência do Plano Real, de seu significado e algumas de suas consequências gerais sobre a crise brasileira segue a trilha da concepção teórico-metodológica presente na sociologia política de Sallum Jr. (1994, 1995, 1999 e 2003).

As transformações encaminhadas no processo do Plano Real refundam o poder político, um novo Estado brasileiro pós-nacional-desenvolvimentista. O Plano Real propicia um salto histórico, uma fase distinta da revolução democrática brasileira, na qual passam a fluir, em novas bases, as incertezas, preferências e escolhas dos atores. Ao ser eleito em 1994, FHC disse, em discurso no Senado Federal, que aquelas eleições encerraram a transição e consolidaram a democracia. A transição democrática deu-se ao mesmo tempo que a crise de poder do Estado desenvolvimentista. A ideia de FHC é compreensível na medida em que, desde o Plano Real, o regime democrático passa a mover-se num novo padrão de poder de Estado, ao que se chegou por um processo que rearranjou as esferas sociopolítica e político-institucional. Isso não significa fazer juízo de valor aprobativo do Plano Real, porque a reforma monetária e as mudanças estruturais a ela vinculadas não têm tido eficácia no cumprimento de algumas de suas metas e promessas fundamentais: recuperação da capacidade de investimento do Estado, desenvolvimento econômico, geração de emprego e justiça social. Novas e antigas contradições passam e continuam a desafiar os atores dominantes e dominados na etapa histórica liberalizante efetivada desde as eleições de $1994 .^{7}$

Marques, avaliando a literatura sobre o Estado no Brasil, considera que esse campo de estudos

7 Consultar "Exposição de Motivos da Medida Provisória do Plano Real" $(30 / 6 / 1994)$. 
"se encontra esgarçado entre uma produção ampla com preocupações teóricas e macrossociológicas e uma miríade de estudos de caso muito detalhados e específicos, oriundos em grande parte de áreas concretas de política. [...] Acredito que uma das principais tarefas para superarmos tal problema está na construção de pontes entre os modelos de interpretação do Estado e a análise concreta de políticas específicas". (2006, pp. 16-17)

Este trabalho quer contribuir para essa perspectiva de mediação.

A articulação entre as esferas econômica, sociopolítica e político-institucional visa buscar ganhos panorâmicos, mas não se ignora que a ampliação do foco implica também em perdas. As contribuições deste trabalho não esgotam a pesquisa. Ademais, visa-se fazer uma interpretação política ampla da crise do Estado desenvolvimentista e de sua supe-

148 ração pelo Plano Real, não se tratando de um trabalho de ciência econômica.

Seguem-se três seções para expor o argumento explicativo mencionado. Na primeira, abordarei elementos da origem, natureza e processo da crise multidimensional. A segunda seção expõe duas interpretações políticas dessa crise. Por fim, será abordada a conjuntura de surgimento do Plano Real para responder como e por que essa policy virou uma página da história brasileira, o que envolverá uma avaliação geral do processo político desde 1994-1995.

\section{Origens e sintomas da crise}

Quando Itamar Franco tomou posse, o país passava por uma crise multidimensional. Sua origem mais profunda remonta ao início dos anos 1980. Um componente desencadeador fundamental dessa crise foi a ruptura do padrão de financiamento do Estado desenvolvimentista, ensejada pelo desequilíbrio das contas externas provocado pelo choque exter- 
no ocorrido entre 1978-1982. O choque externo inclui um conjunto de fatores que repercutiram profundamente nas condições internas e internacionais de financiamento do setor público brasileiro (Baer, 1993, p. 71). ${ }^{8}$ As principais manifestações do choque externo foram: a deterioração contínua das relações de troca, provocada, principalmente, pela elevação dos preços internacionais do petróleo, que muito contribuiu para o déficit comercial brasileiro; a forte alta das taxas de juros nos EUA, que repercutiu em abrupta elevação do já então preocupante endividamento externo do país; por fim, a repercussão, no mercado financeiro brasileiro, das mudanças no mercado internacional, que provocaram a exacerbação da tendência interna de concentrar as operações no curto prazo e a substituição de créditos externos por financiamentos internos, ensejando a "ciranda financeira”. Esse processo macroeconômico articulou-se à aceleração da inflação, especialmente a partir de 1979. A explicitação do choque externo ocorreu em 1982, quando, em resposta à decretação da moratória pelo México, bancos privados internacionais cortaram o financiamento dos endividados e passaram a exigir o pagamento do serviço da dívida contraída.

A resposta da equipe econômica à crise da dívida externa ficou conhecida como "ajuste externo". No final de 1980, o governo executou medidas ortodoxas de combate à inflação, tendo como foco principal o déficit público. A redução brusca nos investimentos das estatais, associada a outras medidas ortodoxas restritivas ao crédito e ao consumo interno, levou o país a uma recessão histórica, entre 1981 e 1983, que marcou o início do colapso do Estado nacional-desenvolvimentista mais bemsucedido da América Latina. Estava praticamente ruído

${ }^{8}$ A síntese aqui apresentada sobre o choque externo e a política de ajuste está em Baer (1993). 
o esquema de financiamento do investimento produtivo, que se estruturava no endividamento externo e no investimento estatal (direto e indireto), assim como nos subsídios do Estado ao setor privado (Bresser Pereira, 1992, pp. 40-44). Após as eleições de 1982, o governo formalizou acordo com o FMI visando receber empréstimos emergenciais para pagar os compromissos com a dívida. ${ }^{9}$ A orientação geral da política econômica foi ajustar as contas públicas para saldar as obrigações com os credores internacionais. Mas as políticas adotadas não debelaram a inflação, pelo contrário, agravaram-na, além de terem aprofundado a deterioração das contas públicas, combinando perversamente endividamento externo e interno. Apesar do bom desempenho exportador resultante do ajuste, sobretudo desde 1983-1984, a crescente dívida externa desequilibrou estruturalmente as finanças públicas brasileiras. Assim, do ponto de vista estritamente 150 macroeconômico, o choque externo e a política de ajuste adotada para enfrentá-lo estão na base da crise fiscal do Estado, de forte componente financeiro. Enfim, esse é o cenário de esgotamento do padrão de financiamento do desenvolvimentismo-autárquico.

$\mathrm{O}$ ajuste externo recessivo executado pelo governo Figueiredo teve um impacto sociopolítico crucial: a rachadura na estrutura de poder que sustentava o Estado desenvolvimentista. ${ }^{10}$ Isso será retomado na próxima seção, mas antecipo que a opção governamental de ajustar as contas públicas resguardando os interesses do capital financeiro, em detrimento da atividade produtiva, pública e privada, descontentou o empresariado industrial, setores da alta

\footnotetext{
9 Os documentos do acordo do Brasil com o FMI estão em "Documentos", Revista de Economia Política, vol. 3, nº 4, 1983, pp. 139-156.

${ }^{10}$ A exposição completa do argumento sobre a crise do pacto de dominação está em Sallum (1995).
} 
burocracia das empresas estatais e os assalariados. ${ }^{11}$ Os trabalhadores não faziam parte do pacto de dominação desenvolvimentista e estavam em plena expansão de suas lutas sindicais e políticas contra o autoritarismo. Mas as outras duas forças sociais mencionadas incluíam-se no pacto. Essa situação de rachadura no pacto de dominação desenvolvimentista, combinada com a crise do regime autoritário, configura uma crise de hegemonia (Gramsci, 2000, pp. 60, 95-96, 184), que atravessará a transição democrática e perdurará até a reconstrução da hegemonia liberal no processo do Plano Real.

A crise de hegemonia do pacto de dominação tem também uma dimensão de crise ideológica. ${ }^{12}$ Durante os anos 1980, as forças até então acomodadas na aliança desenvolvimentista - aliança que nunca foi estática - dividem-se, grosso modo, em duas grandes posições: por um lado, as que perseveram no nacional-desenvolvimentismo e, por outro, as que aderem à perspectiva neoliberal. Mas, ao longo da década, forças sociopolíticas importantes do partido desenvolvimentista vão se convertendo, de um ou outro modo, ao neoliberalismo internacionalmente hegemônico. Em especial, o grande empresariado industrial desenvolvimentista, desde a Nova República, vai se incorporando ao partido liberal, bloco sociopolítico heterogêneo, que se fortalece, conquista posições na esfera político-institucional, mas encontra dificuldades para alterar as relações entre Estado, mercados e sociedade e recriar, ao seu modo, o poder polí-

\footnotetext{
${ }^{11} \mathrm{Um}$ dado empírico representativo do processo de rachadura no pacto de dominação é o "Documento dos Doze", publicado em 1983, no âmbito do "Fórum de Líderes Empresariais", fundado pela Gazeta Mercantil, em 1977. Evocando "a estratégia grandiosa do Plano de Metas", o empresariado desenvolvimentista oferece "à Nação um conjunto articulado de ideias que possa orientar a reconstrução do país". O documento está disponível em: http//www.lideres.org.br/telas/documentos/default.asp?id_interno=2. Acesso em: 15 set. 2007.

${ }^{12}$ Para uma distinção entre hegemonia e ideologia, consultar Cardoso (1993, p. 184).
} 
tico desestruturado com a crise do modelo nacional-desenvolvimentista. ${ }^{13}$

Doze "planos" de estabilização monetária foram produzidos entre 1979 e 1991, envolvendo, de Figueiredo a Collor, sete ministros da Fazenda. O dinheiro se chamou Cruzeiro (1970-1986), Cruzado (1986-1989), Cruzado Novo (1989-1990), novamente Cruzeiro (1990-1992), Cruzeiro Real (1992-1994) e houve um sistema bi-monetário no primeiro semestre de 1994 (já inserido nas etapas do Plano Real), que abrigou a URV e o Cruzeiro Real. ${ }^{14}$ A hiperinflacão propiciou intensos e produtivos debates, na mídia, universidades e instituições públicas da área econômica, entre ortodoxia versus heterodoxia, gradualismo ou choque etc. Houve um longo processo de aprendizado técnico - por entre tentativas e erros, divergências (como sobre usar ou não o congelamento de preços) e dificuldades políticas (como a de fazer o ajuste fiscal). Nesse processo, surgiu e se aprimorou

152 a teoria neoestruturalista da inflação inercial. À medida que o cenário mudava, policy-makers brasileiros defensores dessa teoria (outrora vinculados aos planos Cruzado e Bresser) incorporaram ou puderam exteriorizar ideias liberais em suas formulações técnicas. Condições conjunturais e vontade política ensejaram que esse legado intelectual gerasse a concreta formulação de uma política de estabilização que, executada, logrou efetividade. Do ponto de vista técnico, o conteúdo do Plano Real funde elementos dos pensamentos estruturalistas cepalinos, clássico e novo, com o mainstream econômico neoliberal. Mas cabe repetir que o conhecimento técnico foi um dos recursos de poder mobilizados no processo do Plano Real. Esse recurso foi conquistado por uma liderança política virtuosa, numa conjuntura determinada, através de ações políticas que, encadeadas a outras

\footnotetext{
${ }^{13}$ Consultar, por exemplo, Velasco e Cruz (1997, pp. 77-113).

${ }^{14}$ Consultar Bresser Pereira (1994) e Oliveira (1996).
} 
ações estratégicas também relevantes para a vitória na disputa política em curso, propiciaram a reconstrução, em bases neoliberais, do Estado em crise. ${ }^{15}$

Até a reforma monetária de 1994, a hiperinflação era tão grave quanto difícil de ser resolvida. Grave, por prejudicar, ainda que desigualmente, um conjunto de atores e interesses, abrangendo capital, trabalho, estratos médios e os desfavorecidos em geral. E difícil de ser resolvida, mas menos por motivos técnicos do que por não haver consenso sobre o que e como fazer para superá-la. Embora o ideário neoliberal avançasse entre elites políticas e econômicas, atores ligados ao velho desenvolvimentismo ainda estavam em cena, como o próprio Itamar Franco o foi, sobretudo até meados de 1993. Um exemplo das dificuldades é FHC ter sido o quarto ministro da Fazenda em apenas sete meses de governo Itamar. E, na conjuntura pós-impeachment (1992-1994), os partidos de esquerda, então na oposição às reformas liberais, estavam fortes perante o eleitorado, conforme indicavam as pesquisas de intenção de voto.

O atraso brasileiro na execução do ajuste estrutural desenhado no Consenso de Washington desagradava ao FMI. Em 1993, a inflação estava efetivamente caindo na maioria dos países latino-americanos que faziam as reformas liberais, com exceção do Brasil. Apesar de Collor ter implementado políticas neoliberais (abertura comercial, desregulamentação financeira, desestatização, ajuste fiscal e Mercosul), seu governo fracassou nas tentativas de estabilização monetária que realizou. ${ }^{16}$

Alguns consideravam que havia, na sociedade civil, partidos e burocracia pública, uma coalizão inflacionária. Na sociedade civil, essa coalizão abrangeria os empresários

\footnotetext{
${ }^{15}$ Consultar também Filgueiras (2000, pp. 93-116).

${ }^{16}$ A origem do Mercosul remonta à reaproximação entre Brasil e Argentina, promovida por Sarney e Alfonsin. Collor deu continuidade a essa política de integração regional.
} 
beneficiados com a indexação e as corporações sindicais. Outros (mais representativos da opinião predominante) consideravam a hiperinflação uma situação que, por mais que beneficiasse, momentaneamente, a alguns, ameaçava a todos, sendo a sua superação boa para o conjunto da sociedade. Mas a dificuldade estava em definir quem perderia e ganharia, e quanto, com a pax monetária. Por isso, a hiperinflação era também um sério problema político de falta de consenso estratégico. As mudanças que as agências internacionais e os grandes capitais globais queriam que o Brasil fizesse, para redefinir relações com a economia mundial, implicariam alterações profundas, com custos e benefícios incertos, ao menos em curto prazo, para agentes econômicos, elites políticas, assalariados e burocracia pública. Enfim, se a crise produzia riscos e incertezas, os caminhos de sua superação, também.

A compreensão das dificuldades de produção de consenso requer considerar a existência de uma sociedade civil complexa, diversificada - constituída na modernização conservadora do regime autoritário e na redemocratização -, que conquistara relativa autonomia da tutela estatal corporativista instituída na Era Vargas; e requer qualificar a democracia brasileira, já então uma poliarquia, com direitos civis, políticos e sociais, eleições regulares, voto universal e secreto, multipartidarismo e sistema federativo. Collor menosprezou essas transformações. ${ }^{17}$

Na esfera político-institucional, uma expressão da crise era, obviamente, a própria dificuldade governamental de superar a hiperinflação. Mas, nessa esfera, a crise também se expressava nas eleições e nos partidos. Na primeira eleição presidencial do pós-autoritarismo, em 1989, houve vinte e duas candidaturas. As que chegaram ao segundo turno, as de Collor e Lula, eram explicitamente de oposição ao

\footnotetext{
${ }^{17}$ Consultar Sallum e Kugelmas (1993) e Sallum (1994).
} 
combalido governo Sarney. Brizola, também de oposição, quase chegou ao segundo turno. As candidaturas dos dois principais partidos da Aliança Democrática (coalizão que deu sustentação institucional à Nova República), PMDB e PFL, correram fora do páreo e alcançaram votação inexpressiva. Esse resultado foi o veredicto condenatório dos eleitores a um governo que tomara posse erguendo para a sociedade a bandeira da mudança ampla, mas findara em crise. Mas mais ainda que uma crise de governo era uma crise ampla do Estado, uma crise de hegemonia, de ausência de consenso sociopolítico, que minava a governabilidade desde o início dos 1980, salvo alguns momentos excepcionais de expectativas esperançosas, como em 1986, no Plano Cruzado.

Entre as sete principais candidaturas presidenciais às eleições de 1989, pode-se arriscar a fazer a seguinte classificação ideológica: direita-liberal, Collor (PRN), Afif (PL-PDC) e Maluf (PDS); centro, Ulysses Guimarães (PMDB); centro-esquerda, Brizola (PDT) e Covas (PSDB); e esquerda, Lula (PT-PC do B-PSB). No segundo turno, o PSDB apoiou, dividido, a candidatura de Lula, muito mais por racionalidade eleitoral e valores democráticos (afinal, Collor tinha um passado de compromisso com o regime militar e as oligarquias) do que por substantivas afinidades programáticas com a frente de esquerda liderada pelo PT. Ficou célebre o discurso de despedida de mandato do então senador e virtual candidato à Presidência, Mário Covas, em junho de 1989, no qual ele disse que o Brasil precisava de um choque de capitalismo para enfrentar seus problemas. Mas então o nascente PSDB apenas iniciava sua conversão liberal à qual, até mesmo o PT, que de 1994 a 2002 fez oposição às políticas do pensamento único, também aderiu, à sua maneira, no âmbito da política macroeconômica. ${ }^{18}$

\footnotetext{
${ }^{18}$ Desde 1999, a política macroeconômica compõe-se de um tripé liberal: câmbio flutuante, metas de inflação e superávit primário. Foge do intuito desse trabalho avaliar quais seriam as possibilidades efetivas da esquerda democrática, com vo-
} 
Collor construiu sua candidatura como um outsider. Equipou-se com um marketing político competente. As classes dominantes aderiram mesmo à sua campanha eleitoral apenas no segundo turno. ${ }^{19}$ No primeiro, as preferências eleitorais das burguesias dividiram-se entre as principais candidaturas da direita à centro-esquerda. $\mathrm{O}$ temor do empresariado à vitória de Lula era muito grande. Um exemplo disso foi a declaração do então presidente da Fiesp, Mário Amato, proferida no calor da disputa do segundo turno, ameaçando que 800 mil empresários deixariam o país caso Lula fosse eleito. Assim, embora o país tenha ingressado mais claramente na produção de políticas públicas neoliberais com Collor, o fez em bases sociopolíticas e político-institucionais frágeis. De Sarney a Collor, ocorrem metamorfoses da agenda pública, que transita, desde que Funaro saiu da Fazenda, de uma pauta maximalista (desenvolvimento com distribuição de renda e justiça social) para minimalista (mercadocêntrica).$^{20}$

Mas a crise era tão aguda que, mesmo com frágeis bases parlamentares e laços orgânicos com o empresariado, Collor logrou aprovar no Congresso, em curto prazo, um invasivo e impopular plano de estabilização, que sequestrou os ativos financeiros. A aprovação do Plano Collor no Congresso, com amplo respaldo da mídia, foi uma prova da importância que a agenda da estabilização vinha tendo na nova democracia brasileira. Provou também que o presidencialismo de coalizão não era a causa dos males que impediam a estabilização monetária. ${ }^{21}$ Mas o Plano Collor

\footnotetext{
cação para o governo, e não para o isolamento em relação à sociedade, construir alternativas às poderosas tendências materiais e ideológicas neoliberais.

${ }^{19}$ Sobre a ascensão e queda de Collor, consultar Skidmore (2000).

${ }^{20}$ Consultar Diniz (1997) e Sallum (1995, pp. 139).

${ }^{21}$ Sobre as relações entre as medidas de interesse do governo Collor e o Congresso Nacional, consultar Figueiredo e Limongi (1999). Nas pp. 120-121, podem-se ver as dificuldades de Collor, no Congresso, sempre que ele optou por confrontar-se com o PMDB. Uma crítica ao reformismo político-institucionalista de então está nas pp. 157-158.
} 
evidenciou para os atores da cena política que planos que violassem contratos e regras de mercado não seriam mais tolerados pela sociedade civil.

O impeachment foi o maior trauma que a nova democracia brasileira enfrentou e uma expressão ímpar da crise e da ausência de projetos consistentes para um país envolto em perene estagflação. Embora o impedimento de Collor tenha ocorrido sem rupturas institucionais e em contexto de grande participação da sociedade civil, Itamar Franco assumiu o governo de um Estado que navegava à deriva das expectativas da comunidade nacional e do sistema internacional.

Essa reconstrução da crise multidimensional quis elucidar, preliminarmente, os quatro pontos inter-relacionados do argumento explicativo mencionado no início do artigo: 1) o caráter estrutural da crise econômica, desencadeada pela ruptura do padrão de financiamento do modelo nacional-desenvolvimentista e agravada pelas políticas implementadas para enfrentá-la; a forte tendência liberal das políticas reformistas postas como solução da crise por interesses internos e externos em contexto de globalização; 2) a crise de hegemonia do pacto de dominação desenvolvimentista e a dificuldade de consolidar uma estrutura política alternativa de poder; 3) a crescente hegemonia ideológica liberalizante entre as elites políticas, econômicas, grande mídia e intelectuais, embora tais forças fossem, até então, um bloco sociopolítico heterogêneo e desorganizado; 4) a dimensão político-institucional da crise do Estado, expressa na crise do regime militar, nas dificuldades de governabilidade na democracia (do fracasso do Plano Cruzado até o Plano Real) e nas debilidades das coalizões eleitorais e de governo.

A próxima seção abordará duas vertentes teóricas, presentes nas ciências sociais brasileiras no início dos anos 1990, sobre a natureza da crise para, depois, confrontá-las com o processo de mudança desencadeado pelo Plano Real: a visão 
da crise como crise de hegemonia do pacto de dominação (já parcialmente apresentada) e a abordagem predominante, de que se tratava de uma crise de natureza político-institucional. Elas serão expostas na ordem mencionada.

\section{Duas visões da crise}

Nos anos 1980, operou-se uma interação entre duas crises políticas analiticamente distintas: a crise do Estado desenvolvimentista e a crise do regime autoritário. Aqui se entende por Estado a dimensão que "diz respeito à articulação entre o poder político e o conjunto do corpo social, isto é, a realidade social perpassada por conflitos fundados em diferenciações interclasses e intraclasses”, enquanto regime remete à esfera político-institucional, às regras, normas e valores que balizam a disputa, o exercício, o controle e a distribuição do poder político (Sallum e Kugelmas, 1993, pp. 280; Sallum, 1995, pp. V). ${ }^{22}$

A origem do Estado desenvolvimentista remonta ao período aberto pela Revolução de 1930, desde quando se constrói a aliança desenvolvimentista (Cardoso, 1993, pp. 51-78), à qual Evans (1980, pp. 42-44) denominou tríplice aliança, composta pelo grande capital multinacional, a alta burocracia dirigente das empresas estatais e diversas frações das burguesias brasileiras. Essa aliança forneceu a base sociopolítica de sustentação do Estado que conduziu a industrialização. A perspectiva sociopolítica do Estado desenvolvimentista o concebe como expressão de um pacto de dominação, uma unidade contraditória e dinâmica de classes e frações. ${ }^{23}$ Três regimes políticos existiram na his-

\footnotetext{
${ }^{22}$ Sallum e Kugelmas tratam Estado e regime como o fazem Cardoso \& Faletto (2004, pp. 217).

${ }^{23} \mathrm{O}$ conceito de pacto de dominação é desenvolvido por Cardoso (1977) e Cardoso e Faletto (2004). Esse conceito tem proximidade teórica com o conceito de bloco no poder, de Poulantzas (1971, pp. 57-85). Consultar também Cardoso (1993, pp. 155-184), que distingue classes dominantes e facções dirigentes.
} 
tória do Estado desenvolvimentista: o Estado Novo (1937-1945), a Democracia Populista (1946-1964) e o Regime Militar-Autoritário (1964-1985). As condições político-institucionais do pacto de dominação variaram.

Não se considera que o Estado desenvolvimentista manteve-se imutável no tempo, tendo apenas variações de regime. Dos anos 1930 aos 1980, a aliança desenvolvimentista apresentou relações internas e externas variadas, como pode ser verificado nas diferenças entre os períodos populista (quando frações sociais do núcleo de poder do aparelho de Estado e do sistema representativo vincularam-se às classes populares urbanas, através da política de massas e das eleições) e autoritário-militar (que excluiu os trabalhadores do arranjo político). O Estado desenvolvimentista e a sociedade, mercado e economia capitalistas que se lhe correspondem mudaram no tempo. $\mathrm{O}$ aparelho estatal modernizou-se e diversificou-se em termos administrativos, burocráticos e institucionais - sobretudo nas áreas de política econômica, financeira e social; os interesses econômicos do setor público ampliaram-se, hierarquizaram-se etc. Essas transformações encadearamse dialeticamente com mudanças nas relações internacionais e na economia mundial, nas classes e frações e nos mercados internos. Mas tais mudanças não alteraram uma característica essencial do Estado desenvolvimentista: ser o agente estruturante e politizado do processo de industrialização do capitalismo brasileiro. O Estado assim atuou esteado numa aliança desenvolvimentista que interagia em equilíbrio dinâmico, articulando conservação e mudança. A co-relação de forças sociopolíticas na aliança passou por alterações nos seus vínculos intrínsecos e extrínsecos. ${ }^{24}$

${ }^{24}$ Consultar Draibe (1985), Sallum (1994) e Cardoso e Faletto (2004, p. 219). 
Sallum Jr. (1994 e 1995, pp. 57-58) identifica em 1983 a gênese da ruptura do pacto de dominação desenvolvimentista, na conjuntura de irrupção da crise estrutural desencadeada pelo choque externo. A equipe econômica do governo Figueiredo enfrentou o choque com um ajuste ortodoxo, segundo diretrizes do FMI. As políticas resultaram na retração dos gastos correntes e dos investimentos públicos; resguardaram interesses do capital financeiro externo e interno, mas trouxeram a recessão, transferindo custos para as empresas estatais e para o empresariado industrial. A rachadura na aliança desenvolvimentista delineou duas vertentes estratégicas divergentes quanto aos caminhos de superação da crise: por um lado, os nacional-desenvolvimentistas, que propõem o "saneamento financeiro do setor público", entre outros, preservando a capacidade produtiva das empresas estatais estratégicas e o fechamento das que não possuíam condições de recuperação; ${ }^{25}$ por outro, os

160 neoliberais, identificáveis mais claramente no setor agroexportador e no empresariado comercial. ${ }^{26}$

Nesse contexto, eclode uma crise do Estado de vários conteúdos. Em termos macroeconômicos, ela é financeira e fiscal. Segundo a tradição de sociologia política aqui adotada, ela tem conteúdos de crise de poder (crise de hegemonia do pacto de dominação nacional-desenvolvimentista) e de crise ideológica nas principais forças sociais e partidárias. Por fim, na perspectiva político-institucional, manifesta-se como crise do regime autoritário-militar e crise de governabilidade, esta última rompendo desde o

\footnotetext{
${ }^{25}$ Consultar o referido "Documento dos Doze", de 1983 (ver nota 11).

${ }^{26}$ As oscilações ideológicas e de política econômica, desde então e ao longo da década, expressam o curso dessa clivagem no pacto de dominação, entre, grosso modo, desenvolvimentistas e neoliberais. A solução dessa crise de hegemonia passou pela conversão dos desenvolvimentistas às políticas liberais, que constituiu o heterogêneo partido liberal, dirigente do pacto de dominação cuja reconstrução foi consolidada desde o Plano Real.
} 
colapso do Plano Cruzado e perseverando até as vésperas do Plano Real. ${ }^{27}$

A crise do Estado desenvolvimentista tinha, então, quatro dimensões: macroeconômica, sociopolítica, ideológica e político-institucional. ${ }^{28} \mathrm{O}$ objetivo aqui é argumentar que o sucesso do Plano Real explica-se por ele ter sido, na verdade, o carro-chefe de um programa de políticas formuladas e implementadas para materializar um projeto alternativo e estratégico de reconstrução do poder, e assim o foi a ponto de resolver os quatro elementos constitutivos da crise do Estado.

Por outro lado, havia então a visão político-institucional da crise, que a explicava como crise de governabilidade. Esse enfoque dirigia-se mais precisamente ao que acima foi definido como regime, em distinção a Estado. A principal bandeira política dos atores adeptos dessa interpretação da crise era o parlamentarismo.

A visão político-institucional da crise era muito presente na ciência política brasileira, mas também entre economistas e elites políticas. ${ }^{29}$ Eis uma referência límpida dessa visão:

"o problema central do sistema político brasileiro é o déficit da capacidade de governo. [...] a incapacidade de governar é um efeito da estrutura presidencialista brasileira" (Andrade, 1993, pp. 14-15 - grifos do original).

\footnotetext{
${ }^{27}$ As expressões institucionais da crise do regime militar são inúmeras, como o desempenho eleitoral dos partidos de oposição nas eleições de 1982, a campanha das diretas-já e a própria vitória da candidatura de Tancredo-Sarney no colégio eleitoral. Ver Skidmore (1988, pp. 409-489).

${ }^{28}$ Sobre a crise fiscal do Estado, consultar Bresser Pereira (1992). Para uma distinção entre crise de poder e crise de governabilidade, consultar Martins (1995). Sobre o conceito de governabilidade e para uma crítica ao hiperinstitucionalismo, consultar Melo (1995).

${ }^{29}$ Serra (1995, pp. 24-32) é um exemplo de economista e de político que enfatizava a centralidade político-institucional da crise. Para ele, a inexistência de instituições políticas adequadas era o principal obstáculo à superação da crise econômica. A solução passava pela reforma política (parlamentarismo, voto distrital misto, reforma partidária).
} 
Os defensores dessa abordagem não ignoravam os elementos econômicos e sociais da crise, mas a essência de seu diagnóstico era a esfera político-institucional. Por conseguinte, a estratégia de mudança deveria iniciar-se na reforma política, destinada a recuperar a efetividade da capacidade de governar. Essa perspectiva pode ser encontrada na própria Constituição de 1988, na qual os constituintes derrotados em plenário no intuito de aprovar o parlamentarismo lograram, no entanto, incluir, nas disposições constitucionais transitórias, um plebiscito sobre forma e sistema de governo, a realizar-se em 1993. A principal causa da ingovernabilidade estaria no sistema presidencialista de governo, visto como esgotado, incapaz de constituir coalizões partidárias consistentes, condenado à paralisia decisória, sobrecarregado por demandas e esquemas corporativistas, mergulhado na corrupção, envolto num sistema federativo descentralizado e inoperante. Mas

162 o diagnóstico ia além. Apontava-se a insustentável combinação entre presidencialismo e sistema eleitoral proporcional. Defendia-se a reforma dos sistemas partidário e judiciário etc. As mudanças vistas como necessárias nas instituições políticas variavam conforme a avaliação que se fazia dos problemas do sistema político, tal como ainda ocorre hoje. ${ }^{30}$

O enfoque pluricausal aqui adotado não nega - ao contrário, confirma - a existência, naquela conjuntura, de crise de governabilidade, nem discorda da importância de medidas de reforma política. Mas a agenda pública da ingovernabilidade era, então, hiperinstitucionalista (Melo, 1995, pp. 23-48). Acreditava-se que a classe política precisava, primeiramente, reformar as instituições políticas, para dar ao sistema político as condições de governabilidade e capacidade decisória previamente necessárias ao enfrentamento da cri-

\footnotetext{
${ }^{30}$ Consultar Lamounier e Nohlen (1993), Andrade (1993) e Almeida (1993).
} 
se econômica. A crítica aqui feita a essa abordagem hiperinstitucionalista considera que o processo do Plano Real resgatou o capital político perdido no mercado da crise por atingi-la em seus fundamentos mais profundos, que englobavam a esfera político-institucional, mas iam além dela. É chegada a hora de embasar o argumento, reconstituindo e avaliando o processo do Plano Real.

\section{O processo do Plano Real e sua efetividade}

Como um governo em crise, em paralisia decisória, produziu uma política pública que mudou a história? Por que o Plano Real é um marco na história brasileira atual? O desafio aqui é responder a essas duas questões, que envolvem o arremate de todo o argumento explicativo mencionado no início e já parcialmente desenvolvido. ${ }^{31}$ Uma resposta sintética é que: 1) a crise de governabilidade foi superada pela clássica interação política entre conjuntura e liderança legíti$m a$, ou seja, pela ação política circunstanciada e de vocação hegemônica; 2) o Plano Real envolveu uma profunda interação entre Executivo, Legislativo, Judiciário, partidos políticos, entes federativos subnacionais, diversos agentes econômicos, grande mídia e outros atores da sociedade civil, resultando na emergência sincronizada, nas esferas sociopolítica e político-institucional, de um pacto de dominação liberal que superou a crise de hegemonia e inaugurou um novo padrão de Estado no Brasil.

Os principais elementos conjunturais da crise, nos primeiros meses do governo Itamar Franco, eram:

1. o fortalecimento da conversão à ideologia liberal das elites políticas, partidos, burguesias, grande mídia e estratos superiores da burocracia pública;

\footnotetext{
${ }^{31}$ Essa seção tem forte apoio em fontes primárias, sobretudo a grande imprensa dos idos de 1993-1995.
} 
2. o atraso da estabilização brasileira em relação a outros países latino-americanos, que incomodava as organizações multilaterais;

3. o acúmulo de aprendizado técnico com as políticas de estabilização anteriormente fracassadas e um maior consenso de que o combate à inflação passava pelo ajuste fiscal;

4. a crescente percepção, no imaginário da opinião pública, de que a crise inflacionária era a grande questão a ser resolvida pelo governo;

5. condições econômicas favoráveis, muitas delas derivadas de medidas adotadas desde o governo Collor, para que uma estabilização liberalizante pudesse ser formulada;

6. dificuldades políticas para a implementação da estabilização (fraca coalizão de governo, pouco tempo restante de mandato, apatia);

7. um calendário constitucional que previa:

7.a. o plebiscito sobre forma e sistema de governo em abril de 1993;

7.b. a revisão constitucional a ser iniciada em outubro de 1993, cujas emendas não careciam de quórum qualificado para aprovação;

7.c. eleições presidenciais em outubro de 1994.

Outro elemento conjuntural importante, que surgirá no final de 1993, será o escândalo que resultará na CPI do Orçamento.

A coalizão governista de Itamar Franco foi formada basicamente pelos partidos pró-impeachment, exceto o PT: PMDB, PSDB, PDT e PSB. O PFL também fez parte, embora não tenha apoiado o impedimento de Collor. Era uma coalizão ampla, mas sem um programa consistente. Entre 1990 e 1992 a economia esteve em recessão e a escalada inflacionária prosseguia. O início do governo Itamar ocorreu, de fato, na reforma ministerial de maio de 1993, quando FHC, deslocado do cargo de chanceler para o comando 
da Fazenda, propôs-se a combater a inflação com políticas liberalizantes. ${ }^{32}$ A receptividade à nomeação de FHC foi muito positiva, interna e externamente. Mídia, empresariado e suas principais organizações representativas, a maioria dos congressistas, agências multilaterais, enfim, receberam a nomeação de FHC com grande entusiasmo, aumentado ainda mais com o anúncio de sua equipe, que incluiu, ao longo do tempo, entre outros nomes, os seguintes technopols da economia: Edmar Bacha, Winston Fritsch, Gustavo Franco, Pedro Malan e, sobretudo, a dupla Larida, formada por André Lara Resende e Pérsio Arida. Bacha, Lara Resende e Arida formaram a trinca do Plano Cruzado, em 1986. Nas eleições daquele ano, ficara evidente o grande peso político-eleitoral da estabilização monetária. Inclusive, graças à onda do Cruzado, FHC elegera-se, então, senador pelo PMDB.

Ao assumir a Fazenda, FHC tornou-se virtual candidato à Presidência da República, por uma conjunção de interesses, dele, do PSDB, de Itamar Franco, dos meios de comunicação e do empresariado. No entanto, a candidatura de FHC só foi se confirmando ao longo da implementação do Plano Real. As eleições de 1994 se aproximavam e buscavase uma terceira via, uma alternativa de centro à polarização esquerda-direita, em razão do provável confronto que ocorreria entre Lula e Maluf, segundo as projeções das pesquisas de opinião. Assim, a conjuntura induzia o ministro tucano e o partido liberal no sentido da articulação das agendas econômica e política. O prazo para FHC desincompatibilizar-se do cargo venceria em abril de 1994. O calendário eleitoral praticamente impunha o abandono da perspectiva gradu-

\footnotetext{
${ }^{32}$ Para Bacha (1998, p. 13), FHC foi escolhido para a Fazenda por ser membro influente do PSDB, partido da coalizão de governo, e por ter boas relações pessoais com Itamar Franco. Prado (2005, p. 14), no melhor livro sobre os bastidores técnicos do Plano Real, avalia que FHC foi escolhido por sua capacidade de reunir uma equipe de economistas apta a efetivar a estabilização monetária.
} 
alista de combate à inflação. Mas a sociedade não aceitava mais medidas que violassem regras da economia de mercado. As cobranças por mudanças na economia passaram a aumentar, oriundas da mídia, empresariado, capital estrangeiro, organizações internacionais, Força Sindical. Mas mais que cobrar, forças sociais, incentivadas por FHC, respaldaram-no na vontade de estabilizar a economia e resgatar a credibilidade da ação governamental.

Em junho, o ministro anunciou o Programa de Ação Imediata (PAI), uma primeira sinalização de mudança focada no ajuste das finanças públicas e na reorganização das relações entre os setores público e privado. ${ }^{33}$ Após muitas discussões e pressões, definiu-se a meta de cortar US\$ 6 bilhões do orçamento de 1993. Importantes interesses organizados da sociedade civil deram aprovação ativa ao ministro e formaram o movimento Decola Brasil, que realizou diversos eventos, de junho a agosto, reunindo inte-

166 resses organizados do capital, trabalho assalariado e classes médias. O intuito foi pressionar o Congresso Nacional para a aprovação das medidas de interesse do governo. A Revisão Constitucional aproximava-se e através dela pretendiase avançar nas reformas estruturais. O Decola Brasil é um exemplo representativo, mas se tornará uma ponta do iceberg produzido na repactuação sociopolítica liberal induzida pelo processo da reforma monetária. A aglutinação político-partidária, para viabilizar a aprovação das medidas legislativas de interesse do Executivo, interagiu com a repactuação sociopolítica.

A obstinação de FHC, seu empenho na persuasão da opinião pública e demais atores foram fundamentais. Ele

\footnotetext{
${ }^{33}$ Consultar "Programa de Ação Imediata", Ministério da Fazenda, 1993. O PAI previa: 1) corte e maior eficiência de gastos; 2) recuperação da receita tributária; 3) fim da inadimplência de Estados e municípios em relação às dívidas com a União; 4) controle e rígida fiscalização dos bancos estaduais; 5) saneamento dos bancos federais; 6) privatização.
} 
constituiu, enfrentando resistências e receios, uma equipe de elite de assessores econômicos e políticos e administrou divergências em seu interior. Enfrentou obstáculos no Congresso, em outras esferas do sistema político e na sociedade civil, como os que ocorreram durante a votação da política salarial, em meados de 1993, e noutros momentos da implementação do Plano Real. O apoio da mídia ao plano de estabilização foi fundamental, como o foi também a estratégia de comunicação adotada pelos formuladores do plano de estabilização. ${ }^{34}$ A essa altura, a opção parlamentarista, apesar do amplo apoio que recebera da mídia e de elites políticas e econômicas, já havia ficado para trás, com a folgada vitória do presidencialismo no plebiscito de abril. Mas o parlamentarista FHC não se desanimou, foi à luta para reunir os meios técnico-econômicos, sociopolíticos e político-institucionais necessários à realização do plano de estabilização monetária tão cobrado por atores internos e externos ao país. FHC foi, simultaneamente, autor e personagem da superação da crise de hegemonia.

Outros fatos relevantes naquela conjuntura, entre o final de 1993 e o início de 1994, foram o escândalo de corrupção, que resultou na CPI do Orçamento, e a Revisão Constitucional. A CPI deixou o Congresso acuado perante o Executivo e a opinião pública e envolveu três dos principais partidos nas irregularidades: PMDB, PFL e PPR. ${ }^{35} \mathrm{~A}$ revisão fracassou pelo menos por três fatores: o escândalo que resultou na CPI do Orçamento; a pressão dos contras - organizações da sociedade civil (OAB, ABI, CNBB, CUT, UNE) e partidos (PT, PDT, PSB, PC do B e PSTU) que se

\footnotetext{
${ }^{34}$ Consultar Prado (2005, pp. 226-245).

${ }^{35}$ Lembre-se que a corrupção já havia traumatizado o país no impeachment. Sobre o quanto a CPI dos Anões facilitou a aprovação do Plano Real no Congresso, consultar Cardoso (2006, pp. 205). Em 2007, o PFL passou a se chamar Democratas (DEM). O PPR surgiu em 1993, da fusão PDS-PDC. Em 1995, a fusão PPR-PP origina o PPB. Em 2003, o PPB tira o "B" da sigla e passa a se chamar PP.
} 
opuseram a ela; e pela proximidade das eleições de 1994, que dispersou a presença dos parlamentares nas sessões e dificultou a votação de temas polêmicos. No entanto, a esperança depositada nas reformas da Revisão foi-se deslocando para o horizonte que se abria à medida que a candidatura presidencial de FHC se confirmava.

O lançamento do Plano Real ocorreu em dezembro de 1993. Veio composto de três fases: a do ajuste fiscal, a de criação de um novo indexador (Unidade Real de Valor - URV) e a de introdução da nova moeda. Uma quarta fase, que não veio detalhada, mas tinha suas diretrizes explicitadas, seria a das reformas estruturais. ${ }^{36} \mathrm{Na}$ realidade, essas fases não são meramente sequenciais ou lineares, sobrepõem-se e envolvem um conjunto de políticas, monitoramentos das já iniciadas e formulação e implementação de outras. Além disso, articulam-se ao PAI, à elevação das taxas de juros (para aumentar as reservas cambiais que las168 treariam a nova moeda), à sobrevalorização cambial e a medidas de abertura comercial com fins antiinflacionários. Algumas ações aprofundavam políticas iniciadas por Collor, outras foram introduzidas em 1993 e 1994. A viabilidade do Plano Real pressupunha a continuidade da implementação e monitoramento das políticas propostas e a formulação de novas medidas liberalizantes. Assim, era imprescindível a vitória de uma candidatura presidencial comprometida com a manutenção e expansão desse abrangente programa de reformas.

A etapa fiscal do plano requeria, de imediato, a aprovação, por emenda constitucional encaminhada ao Congresso Revisor, de um Fundo Social de Emergência (FSE), formulado com a meta de alcançar equilíbrio orçamentário em 1994. Em síntese, o FSE era uma desvinculação de $20 \%$ das transferências constitucionais para Estados, municípios, fun-

\footnotetext{
${ }^{36}$ Consultar "Exposição de Motivos da MP do Plano Real".
} 
dos regionais e algumas políticas sociais. A previsão inicial era cortar US\$ 16,1 bilhões do orçamento para destiná-los, sobretudo, ao pagamento das despesas com juros da dívida pública. Ao final, chegou-se ao montante de US\$15,5 bilhões. As negociações para a aprovação do FSE, que não tinha nada de social, foram muito difíceis. ${ }^{37}$ Envolveram concessão de ministérios aos partidos da base governista, perdão de dívidas de agricultores, redução do prazo de desincompatibilização para governadores se recandidatarem às eleições, concessões a Estados e municípios, além da prorrogação do prazo da Revisão Constitucional. Foi uma negociação que envolveu todo o setor político e contou com o apoio do empresariado. ${ }^{38}$ Itamar Franco e vários ministros mobilizaram-se para aprovar o FSE. FHC dirigiu-se à população em cadeia de rádio e televisão e reuniu-se várias vezes com os parlamentares. A base aliada e seus líderes, inclusive parcela expressiva do PMDB, mobilizaram-se para viabilizar a vitória. O FSE foi aprovado pelo Congresso Revisor, em duas sessões unicamerais, em fevereiro de 1994, induzido por um poderoso e representativo processo sociopolítico e políticoinstitucional de construção de consenso. ${ }^{39}$ Para essa vitória, jogou um papel dirigente fundamental a aproximação entre PSDB e PFL, na qual FHC previamente se empenhou muito, tendo em mãos, como principal recurso de convencimento, o virtual capital político contido no plano de estabilização formulado por sua pública e notoriamente crível equipe técnica. Recurso tão mais precioso quando se leva em conta

\footnotetext{
${ }^{37}$ A primeira votação de aprovação do FSE ocorreu em 8/2/1994. Basta consultar os principais veículos de mídia da época para constatar a reação positiva de todo o grande empresariado a essa medida, assim como o anseio de que o processo de estabilização seguisse adiante.

${ }^{38}$ A Revisão Constitucional foi instalada em 7/10/1993 e seu encerramento, inicialmente agendado para 31/3/1994, foi prorrogado para 31/5/1994, a pedido de partidos da base aliada.

${ }^{39}$ Apesar do fracasso da Revisão Constitucional, o governo federal focou-se no FSE e logrou aprovar essa emenda fundamental para o Plano Real.
} 
que Lula estava colocado em primeiro lugar nas pesquisas de opinião sobre a sucessão presidencial. Inclusive, por conta disso, uma entre as poucas emendas de revisão aprovadas foi a redução do mandato presidencial de cinco para quatro anos, de modo que, ocorrendo a vitória do petista nas eleições de outubro de 1994, ele exerceria o governo por menos tempo. Mas esse medo esvaía-se à medida que o Plano Real ganhava terreno e a candidatura de FHC se concretizava, superando os receios dos que temiam que a substituição do ministro, em plena implementação da política de estabilização, poderia prejudicar a efetividade da reforma monetária.

Aprovada a fase fiscal com uma emenda relevante na Constituição de 1988, entrou em vigor, em $1^{\circ}$ de março, a medida provisória 434, da URV. Foi então que se desenrolou a chamada crise dos três poderes (Executivo, Legislativo e Judiciário), aberta pela austeridade fiscal requerida pelo Plano Real. Senadores e deputados federais decidiram auto-

170 conceder-se aumento salarial. Também desafiando o Plano Real, ministros do STF tentaram converter à URV os seus próprios salários e os dos funcionários do Judiciário Federal por meios diferentes dos propostos pelo Executivo. Os funcionários do Legislativo já haviam conseguido realizar essa façanha. Posteriormente, a Federação dos Militares Aposentados e Pensionistas também impetrou ação judicial para garantir uma conversão mais conveniente dos salários de seus funcionários à URV. Após desacordos entre Itamar Franco e FHC, chegou-se a uma solução negociada, conforme desejava o ministro. Assim, a Medida Provisória (MP) da URV foi reedidata, sob o número 457 . A conversão dos salários do setor privado à URV, pela média dos últimos quatro meses, também provocou mobilizações no movimento sindical. No entanto, o sindicalismo de então já não tinha, naquele contexto de desemprego estrutural, tanta capacidade de mobilização, o que facilitou os planos do governo. Ademais, a imediata efetividade da política de estabilização, antes mes- 
mo do real entrar em circulação, ia removendo obstáculos políticos. Uma última reedição da MP ocorreu no final de abril, sob o número 482, envolvendo correções em relação ao salário mínimo e dívidas do setor agrícola. Assim, após três edições e oitenta dias de discussões, a MP da URV foi aprovada em 20 de maio de 1994. Enfim, os ajustes necessários para operar a profunda desindexação na economia foram difíceis. Envolveram negociações sobre salários, pensões e aposentadorias, aluguéis, cadernetas de poupança, financiamentos habitacionais, mensalidades escolares, planos de saúde, seguros e previdência privada, impostos, fundos de investimentos, FGTS e outros contratos.

Em abril, FHC deixou a Fazenda para candidatar-se, já tendo negociado, desde o final de 1993, a concessão ao PFL do cargo de vice-presidente na chapa eleitoral. ${ }^{40} \mathrm{~A}$ aprovação da URV abriu o caminho para a entrada em circulação do real, em primeiro de julho, concluindo uma etapa fundamental da estratégia política de grande envergadura. $\mathrm{O}$ impacto do plano de estabilização sobre a hiperinflação foi imediato.

O Plano Real apoiou-se, parcialmente, mas significativamente, em medidas liberalizantes que vinham sendo implementadas desde o governo Collor, ao mesmo tempo em que as aprofundou. No que diz respeito ao ajuste fiscal, o governo Collor já havia executado medidas rigorosas nesse sentido. ${ }^{41} \mathrm{~A}$ âncora cambial lastreou-se no nível recorde das reservas internacionais, propiciado por um conjunto de políticas: desregulamentação da conta capital e financeira do balanço de pagamentos e elevação da taxa de juros, para atrair poupança externa financeira e produtiva; virtual equacionamento da dívida externa, com base no Plano Brady. A antecipação do calendário que estabelecia reduções de

\footnotetext{
${ }^{40}$ Consultar (Dimenstein e Souza, 1994, pp. 125-138). Ver também Cardoso (2006, p. 187).

${ }^{41}$ Consultar Appy (1993a).
} 
tarifas de importação, a sobrevalorização do real e o aumento das importações também foram medidas utilizadas para combater a hiperinflação. O déficit comercial e o déficit em conta corrente foram indicadores que caracterizaram, respectivamente, o período 1995-2001 e 1995-2002. ${ }^{42}$

Mas a situação política era, em alguns aspectos, desfavorável, pela fraqueza do governo Itamar Franco, por ser ano eleitoral e pela própria pressão para que FHC abandonasse a Fazenda e se lançasse candidato a presidente. No entanto, pesquisas de opinião pública indicavam que o eleitorado priorizava a solução dos problemas econômicos, com ênfase na estabilidade inflacionária, mais que a redistribuição de renda, inclusive devido à ampla propagação ideológica de que o combate à inflação precedia a solução de outros problemas econômicos e sociais e exigia sacrifícios. ${ }^{43}$

A imediata efetividade do Plano Real mudou radicalmente o quadro eleitoral. Até a primeira quinzena de julho

172 de 1994, Lula ainda sustentava o primeiro lugar nas pesquisas de intenção de voto. Mas, desde maio, FHC subia e Lula caía nessas sondagens eleitorais. O resultado é conhecido: a vitória, em primeiro turno, da candidatura da coligação de centro-direita, que reuniu PSDB-PFL-PTB, informalmente ampliada por inúmeros outros apoios partidários regionais. O resultado eleitoral mostrou uma reconstituição políticoideológica do centro em aliança com a direita. ${ }^{44}$ Empos-

\footnotetext{
${ }^{42}$ O Plano Brady, do secretário do Tesouro dos EUA, foi lançado no final dos anos 1980 e estabeleceu as novas bases da renegociação da dívida externa dos países endividados. Manteve as condições do Plano Baker para a aquisição de novos empréstimos (privatizações, abertura comercial e desregulamentação financeira) e inovou instituindo um desconto na dívida dos países devedores.

${ }^{43}$ Consultar Folha de S. Paulo, 16/1/1994.

${ }^{44}$ Não é possível aqui fornecer detalhes da campanha eleitoral de 1994 e dos resultados daquelas eleições. Fernandes (1995) mostra que houve então a reconstituição político-ideológica da centro-direita, indicando a gênese de uma nova hegemonia política no plano partidário. Ela pode ser verificada nos resultados das eleições para presidente, deputados federais e senadores, assim como para os governos estaduais e assembleias legislativas.
} 
sado, FHC formou uma coalizão de governo amplamente majoritária (inclusive para garantir aprovação de emendas constitucionais), e com farta base de apoio nos estados. Desde então não se fala mais em ingovernabilidade como antes se falava. ${ }^{45}$

Sallum Jr. (1999, pp. 30-31 e 2003, p. 11) esclarece que a aliança partidária de centro-direita dá acabamento institucional ao processo sociopolítico de construção da hegemonia liberal. Só discordo de Sallum quando ele considera o Plano Real "apenas uma peça subordinada do 'momento maquiaveliano', cujo elo principal foi a aliança política entre partidos de centro e direita em torno de um projeto de tomada de poder e reconstrução do Estado em uma perspectiva liberal". Penso que o Plano Real viabilizou a repactuação sociopolítica, inclusive o seu acabamento na esfera político-institucional pela aliança de centro-direita. O Plano Real foi a arma oportunamente desembainhada pelo príncipe para organizar um exército liberal até então sem general; foi o programa gerador da força centrípeta que reconstruiu o consenso do qual emergiu o Estado pós-nacional-desenvolvimentista. O Plano Real expressou e conduziu ao poder uma vontade "coletiva" liberal, núcleo ideológico que capturou o interesse público antiinflacionário. $\mathrm{O}$ partido liberal dirigiu a estabilização monetária e a reconstrução do Estado. Se se pensar na concepção gramsciana de hegemonia como reforma intelectual e moral e também como direção, pode-se admitir que o Plano Real converteu em hegemonia política o que se difundia como hegemonia civil (Carnoy, 1994, p. 99), superando a sinergia entre as crises ideológica e política (Poulantzas, 1977, p. 13).

\footnotetext{
${ }^{45}$ Do total arrecadado pelas seis candidaturas presidenciais à eleição de 1994, 97\% foram provenientes de pessoas jurídicas. A candidatura de FHC recebeu $68,5 \%$ do total da arrecadação oficial dos presidenciáveis e 73,5\% da contribuição total das pessoas jurídicas destinadas aos candidatos (fonte TSE).
} 
O enfoque centrado na redefinição do pacto de dominação permite explicar a relativa e contraditória incorporação do PT, de 2002 em diante, ao bloco hegemônico liberal, que tem na estrutura da política macroeconômica adotada uma fonte fundamental de sustentação. ${ }^{46} \mathrm{O} \mathrm{Pla}-$ no Real virou uma página da história do Brasil. Seu programa de mudanças atravessou os dois mandatos de FHC, o primeiro governo de Lula e prossegue no seu segundo mandato.

Desde então, pode-se destacar a execução, entre outras, das seguintes políticas e mudanças institucionais econômicas vinculadas à nova ordem liberal no Brasil: ${ }^{47}$

\section{I. $1 .^{\circ}$ e $2 .^{\circ}$ mandatos de FHC (1995-2002)}

1995: Quebra dos monopólios estatais do petróleo, telecomunicações e distribuição de gás canalizado; fim da reserva de mercado na navegação de cabotagem e das diferenças entre empresas nacionais e estrangeiras; lei da concessão de serviços públicos; ampla delegação de prerrogativas de regulamentação de transações econômicas para o Banco Central (BCB) e o Conselho Monetário Nacional (CMN); formulação do Plano Diretor da Reforma do Estado.

1995: Exposição de Motivos $n^{\circ} 311$ do Ministro da Fazenda ao Presidente da República (abertura bancária).

\footnotetext{
${ }^{46}$ A "Carta ao Povo Brasileiro", publicada por Lula em 22/6/2002, em contexto de campanha eleitoral e instabilidade do mercado financeiro ocasionada pelo "risco PT", marca o compromisso petista com a manutenção da política macroeconômica. Nela, lê-se: "Vamos preservar o superávit primário o quanto for necessário para impedir que a dívida interna aumente e destrua a confiança na capacidade do governo de honrar os seus compromissos".

${ }^{47}$ As fontes do levantamento que se segue são amplas, basicamente as instituições públicas e a grande mídia especializada. As políticas externa e de comércio exterior não serão detalhadas, mas as políticas cambial, monetária e fiscal da Era Real já oferecem parâmetros fundamentais para caracterizar as relações internacionais do país. O Plano Real é um marco na inserção do Brasil na globalização. Por razão de espaço, fica inviabilizada a possibilidade de comprovar o conteúdo liberalizante dessas policies e suas relações causais com alguns indicadores aludidos. Remeto o leitor à bibliografia referida, entre outras.
} 
1995-2002: Profundas privatizações de empresas federais e estaduais em vários setores, sobretudo serviços e infraestrutura, com ampla participação do capital estrangeiro. ${ }^{48}$

1995-2002: Elevação da carga tributária, iniciada em 1994 (quando alcança 29,5\% do PIB), é mantida nesse patamar no primeiro mandato e aumenta ano a ano no segundo governo, chegando a 35,53\% do PIB em 2002.

1995-2002: Fundo Social de Emergência, depois Fundo de Estabilização Fiscal e atual Desvinculação de Recursos da União

1995-1997: Proer (Programa de Estímulo à Reestruturação e ao Fortalecimento do Sistema Financeiro Nacional - SFN) e Proes (Programa de Incentivo à Redução da Presença do Estado na Atividade Bancária).

1996: Criação do Copom (Comitê de Política Monetária) e aprovação da Lei de Patentes.

1996-1997: Primeiras agências reguladoras (Agência Nacional de Energia Elétrica, Agência Nacional de Telecomunicações e Agência Nacional de Petróleo).

1997: Renegociação das dívidas de estados e municípios com a União.

1998: Aprovação da Reforma da Gestão Pública e da Reforma da Previdência; acordo com o FMI.

1999: BCB substitui câmbio fixo pelo flutuante; instituição do sistema de metas de inflação.

1999 em diante: Fixação e cumprimento de metas de superávit primário.

2000: Resoluções $n^{\circ} 2.689$ e $n^{\circ} 2.770$ do CMN (consolidação da abertura financeira).

2000: Lei de Responsabilidade Fiscal.

2002: Revisão do acordo com o FMI.

\footnotetext{
${ }^{48}$ Incluindo todas as privatizações realizadas entre 1991-2000 (PND, governos estaduais e telecomunicações), o capital estrangeiro adquiriu 48,2\% do patrimônio empresarial estatal que foi vendido (fonte: BNDES).
} 


\section{1. ${ }^{\circ}$ mandato de Lula (2003-2006)}

2003: Aprovação da Emenda Constitucional $n^{\circ} 40$ (modifica o art. 192 da CF, que trata do Sistema Financeiro Nacional).

2003: Elevação da meta de superávit primário de $3,75 \%$ para 4 , 25\% do PIB; Reforma da Previdência; aprovação da Emenda Constitucional $\mathrm{n}^{\circ} 42$ (reforma tributária).

2003-2005: Continuação da política de elevação da carga tributária (alcança $37,37 \%$ do PIB em 2005). ${ }^{49}$

2004: Lei das Parcerias Público-Privadas (PPPs).

2005: Nova Lei de Falências.

2006: Lei Geral das Micro e Pequenas Empresas.

No centro hegemônico do novo pacto sociopolítico estão os rentistas - detentores dos ativos financeiros, como os títulos públicos, cuja maior parte é remunerada pelas taxas de juros reais mais altas do mundo, que oneram o elevado endividamento -, o empresariado financeiro e o gran176 de capital internacionalizado da indústria e dos serviços. O grande empresariado brasileiro de todos os setores da economia (primário, secundário e terciário, ligados ao comércio exterior ou ao mercado interno) está associado. As novas classes médias também estão incluídas (alta burocracia dos setores privado e público, profissionais liberais, jornalistas, publicitários, economistas, advogados, professores universitários etc.). Elites organizadas dos assalariados, como as da Força Sindical, também foram incorporadas. Desde a posse de Lula, estratos sociais da elite sindical da CUT, incorporados à administração de fundos estatais e institucionais, ou a cargos importantes em ministérios, outros órgãos públicos e no parlamento, passaram, com o PT e o PG do B, a compor a ala esquerda do bloco hegemônico liberal, por seu apoio à manutenção da política macroeconômica, à qual, em certa

${ }^{49}$ Os dados sobre a carga tributária estão disponíveis no Ipeadata. 
medida, contrabalançam com um conjunto de outras políticas contra-hegemônicas. ${ }^{50}$

O processo de construção do novo pacto de dominação vai dos mercados e da sociedade ao Estado, e vice-versa; produz ganhadores e perdedores; modifica o padrão de capitalismo, de inserção internacional do país e de enriquecimento; implica desnacionalização e concentração de capitais; envolve competição, cooperação e conflito entre forças sociais, econômicas e políticas, inclusive nas elites da burocracia pública.

Concluindo as respostas às questões formuladas no início dessa seção, a efetividade do Plano Real deve-se ao caráter multidimensional de resposta à crise contido em seu processo de formulação e implementação, que: 1) estabiliza a moeda de modo market-oriented; 2) abre alas à passagem de uma ampla agenda de políticas do partido liberal; 3) produz consenso e propicia legitimidade à ação governamental; 4) constrói um pacto de dominação (dinâmico) pós-nacional-desenvolvimentista que reconstrói o Estado; 5) reorganiza o sistema partidário, que passa por uma convergência para o centro do espectro ideológico; 6) torna o sistema político mais governável. São esses os argumentos explicativos do artigo. A interpretação da crise como crise de governabilidade e a avaliação de que a saída era a reforma política, sobretudo o parlamentarismo, apoiava-se numa análise que minimizava os nexos da crise político-institucional com a crise mais ampla (sociopolítica) do Estado, que redefinia, há mais de uma década, relações entre o país, o sistema internacional, os mercados (externo e interno) e as forças sociais. As iniciativas de FHC, tomadas em contexto de presidencialismo e ingovernabilidade, resultantes no Plano Real, tiveram efeitos multidimensionais e confirmam

\footnotetext{
${ }^{50}$ Consultar Pochmann (2003 e 2005), Bresser-Pereira (2007, pp. 255-277), Força Sindical (1993), Oliveira (2003, pp. 146-150) e Nassif (2007, pp. 243-264).
} 
a importância da liderança no processo político das novas democracias (Weffort, 1992, pp. 92-97).

A tradição anglo-saxônica distingue três dimensões da política: política constitucional (polity), política competitiva (politics) e política pública (policy). Esse artigo resgata a dimensão sociopolítica do Estado como pacto de dominação. O processo do Plano Real envolveu a interação e mudança de todas essas dimensões, foi uma grande obra de estruturação política, nos planos do Estado e do regime. O Plano Real foi o carro-chefe de um programa de políticas que ensejou uma multireação à crise multidimensional, contraarrestando-a em seus princípios fundamentais, daí seu significado histórico. A virtù de FHC e de sua equipe foi simultaneamente fundamental e ligada às circunstâncias, não se tratando de uma análise baseada em extremismos voluntaristas ou funcionalistas, nem de redução da explicação causal do sucesso do Plano Real a conhecimento técnico ou 178 apenas a variáveis político-institucionais.

A repactuação sociopolítica induzida pelo Plano Real não se explica pela teoria da conspiração. O FMI, por exemplo, em fevereiro de 1994, negou-se a apoiar formalmente o Plano Real, por rejeitar o componente heterodoxo de sua formulação (teoria da inflação inercial: URV). E embora o plano tenha sido anunciado em fins de 1993, sua formulação foi sendo concluída e alterada na luta pela sua implementação, ao longo e depois de 1994. O Plano Real foi uma aposta no futuro feita na frente de batalha da disputa política. O pacto de dominação liberal não se consolidou por uma adesão límpida e incondicional do grande empresariado a todas as fases do Plano Real. A repactuação sociopolítica ocorreu porque o programa de mudança econômica liderado pela estabilização da moeda agregou a diversidade das frações burguesas no que elas têm de comum, a preservação dos interesses baseados nas relações de propriedade e na existência de condições econômicas de acumulação, 
assim como o compartilhamento, em intensidades diferenciadas, dos elementos ideológicos liberalizantes dominantes no cenário da globalização. Com o Plano Real em mãos, FHC, sua equipe e apoiadores operaram ações políticas de aproximação dos atores, mediadas por instituições políticas e econômicas e circunscritas numa conjuntura histórica da longa crise estrutural.

A grande política pública do Brasil pós-Real tem sido o pagamento das despesas da dívida pública (Souza, 2003, pp. 144-146). O Plano Real surgiu procurando combater a inflação simultaneamente à superação da crise fiscal do Estado, mas a dívida interna elevou-se muitíssimo desde 1994.

"Existe um consenso na literatura sobre análise de políticas públicas de que decisões tomadas no passado constrangem decisões futuras e limitam a capacidade dos governos de adotar novas políticas públicas ou de reverter a rota das políticas atuais" (Souza, 2003, pp. 145-146).

No caso do Plano Real, esse constrangimento tem sido especialmente verdadeiro. A política macroeconômica adotada vem, em sua linha mestra, perdurando no tempo e acarretando sérias limitações orçamentárias para as políticas social e industrial. ${ }^{51}$

O Plano de Aceleração do Crescimento (PAC), anunciado no início do segundo governo Lula, pretende dar um rumo de desenvolvimento à economia. Além disso, Lula tem dado maior prioridade às políticas sociais. O Plano Real virou uma página da história do Brasil, refundou o Estado, rearranjou a esfera político-institucional e delimitou a rota principal das políticas públicas. Mas a dívida social continua imensa e ainda não há um efetivo modelo de desenvolvimento sustentável, promotor do bem-estar social e da equidade.

${ }^{51}$ Ver Bresser Pereira (2007, pp. 235-254) e Fiori (1997, pp. 221-222). 


\section{Marcus lanoni}

\section{é professor do Departamento de Ciências Políticas da UFF}

\section{Referências bibliográficas}

ALMEIDA, M. H. T. de. 1993. "Em defesa da mudança”. Novos Estudos, $\mathrm{n}^{\circ}$ 35, São Paulo: Cebrap.

AMARAL, R. (coord.). 1995. FHC: os paulistas no poder. Niterói: Casa Jorge Editorial.

ANDRADE, R. de. 1993. "A reforma institucional no Brasil". Lua Nova, ${ }^{\circ}$ 28/29, São Paulo: Cedec.

APPY, B. 1993a. "Questão fiscal: crise e concentração de renda”. In: APPY, B. et al. Crise brasileira: anos oitenta e governo Collor. São Paulo: Desep/Inca.

. et al. 1993b. Crise brasileira: anos oitenta e governo Collor. São Paulo: Desep/Inca.

BACHA, E. 1998. "Plano Real: uma avaliação". In: MERCADANTE, A. (org.). O Brasil pós-real. Campinas: Ed. Unicamp.

BAER, M. 1993. O rumo perdido: a crise fiscal e financeira do Estado brasileiro. Rio de Janeiro: Paz e Terra.

BENEVIDES, M. V., VANNUCHI, P. e KERCHE, F. 2003. Reforma política e 180 cidadania. São Paulo: Fundação Perseu Abramo.

BORBA, J. 2002. Análise de politicas públicas: uma revisão da literatura de ciência política sobre o Plano Real e uma proposta alternativa. Niterói: ABCP.

BRANDÃO, G. M. 1998. “A teoria política é possível?”. Revista Brasileira de Ciências Sociais, vol. 13, n 36, São Paulo: Scielo.

BRESSER PEREIRA, L. C. 1992. A crise do Estado: ensaios sobre a economia brasileira. São Paulo: Nobel.

. 1994. "A economia e a política do Plano Real". Revista de Economia Política, vol. 14, n 4 (56), outubro-dezembro.

. 2006. "Estratégia nacional e desenvolvimento". Revista de Economia Política, vol. 26, nº 2 (102), São Paulo: Scielo.

. 2007. Macroeconomia da estagnação. São Paulo: Editora 34:

CARDOSO, F. H. 1977. "Estado capitalista e marxismo". Revista Estudos, Petrópolis-RJ: Cebrap/Vozes.

. 1993. A construção da democracia: estudos sobre política. São Paulo: Siciliano.

2006. A arte da política: a história que vivi. Rio de Janeiro: Civilização Brasileira.

.; FALETTO, E. 2004. Dependência e desenvolvimento na América Latina: ensaio de interpretação sociológica. Rio de Janeiro: Paz e Terra. 
CARNOY, M. 1994. Estado e teoria política. Campinas-SP: Papirus.

DIMENSTEIN, G.; SOUZA, J. 1994. A história real. São Paulo: Ática.

DINIZ, E. 1997. Crise, reforma do Estado e governabilidade. Rio de Janeiro: Fundação Getúlio Vargas.

DRAIBE, S. 1985. Rumos e metamorfoses: um estudo sobre a Constituição do Estado e as alternativas da industrialização no Brasil, 1930-1960, Rio de Janeiro: Paz e Terra.

EVANS, P. 1980. A tríplice aliança: as multinacionais, as estatais e o capital nacional no desenvolvimento dependente brasileiro. Rio de Janeiro: Zahar.

FERNANDES, L. 1995. "A gênese de uma nova hegemonia: as eleições de 1994 e o realinhamento partidário no Brasil”. In: AMARAL, R. (coord.). FHC: os paulistas no poder. Niterói: Casa Jorge Editorial.

FIGUEIREDO, A. C.; LIMONGI, F. 1999. Executivo e Legislativo na nova ordem constitucional. Rio de Janeiro: Ed. FGV.

FILGUEIRAS, L. 2000. História do Plano Real. São Paulo: Boitempo Editorial.

FIORI, J. L. 1997. Os moedeiros falsos. Petrópolis, Vozes.

FORÇA SINDICAL. 1993. Um projeto para o Brasil: a proposta da Força Sindical. São Paulo: Geração Editorial.

GRAMSCI, A. 2000. Cadernos do cárcere, vol. 3. Rio de Janeiro: Civilização Brasileira.

IANONI, M. 1997. O Real no poder: crise de Estado, estabilização econômica e reformas estruturais no Brasil. Tese de Doutorado, PUC-SP.

LAMOUNIER, B.; DIETER, N. (orgs.). 1993. Presidencialismo ou parlamentarismo: perspectivas sobre a reorganização institucional brasileira. São Paulo: Loyola.

MARQUES, E. C. 2006. "Redes sociais e poder no Estado brasileiro: aprendizado a partir das políticas urbanas". Revista Brasileira de Ciências Sociais, vol. 21, nº 60 .

MARTINS, L. 1995. “Crise de poder, governabilidade e governança”. In: REIS VELLOSO, J. P. dos; ALBUQUERQUE, R. C. de (coords.). Governabilidade Ẽ reformas, Rio de Janeiro: José Olympio.

MELO, M. A. B. C. 1995. "Ingovernabilidade: desagregando o argumento”. In: VALLADARES, L.; COELHO, M. Governabilidade e pobreza no Brasil. Rio de Janeiro: Civilização Brasileira.

MERCADANTE, A. (org.). 1998.O Brasil pós-real. Campinas: Ed. Unicamp. NASSIF, Luís. 2007. Os cabeças-de-planilha. Rio de Janeiro: Ediouro.

NORTH, D. C. 1990. Institutions, institutional change and economic performance. Cambridge: Cambridge University Press.

OLIVEIRA, F. de. 2003. "O Ornitorrinco". Crítica à razão dualista - O ornitorrinco, São Paulo: Boitempo Editorial: 
OLIVEIRA, G. 1996. Brasil real: desafios da pós-estabilização na virada do milênio. São Paulo: Mandarim.

PIO, C. 2001. "A estabilização heterodoxa no Brasil: ideias e redes políticas”. Revista Brasileira de Ciências Sociais. São Paulo:

POCHMANN, M. 2003. "O ciclo da financeirização e a distribuição funcional da renda no Brasil”. In: Jornal do Diap, Brasília: agosto/ setembro.

. et al. 2005. Atlas da exclusão social, vol. 3: os ricos no Brasil, São Paulo: Cortez.

POULANTZAS, N. 1971. Poder político e classes sociais no Estado capitalista. Porto: Portucalense, vol. 2.

. 1977a. "As transformações atuais do Estado, a crise política e a crise do Estado”. In: (dir.). O Estado em crise, Rio de Janeiro: Graal. (dir.) 1977b. O Estado em crise, Rio de Janeiro: Graal.

PRADO, M. C. R. M. do. 2005. A real história do real. Rio de Janeiro: Record.

REIS, E. P. 2003. "Reflexões leigas para uma agenda de pesquisa em políticas públicas”. Revista Brasileira de Ciências Sociais, vol. 18, nº 51, São Paulo: Scielo

182 REIS VELloso, J. P. dos; AlBUQUERQUE, R. C. de (coords.). 1995. Governabilidade Ẽ reformas, Rio de Janeiro: José Olympio.

REVISTA DE ECONOMIA POLÍTICA. 1983. vol. 3, $\mathrm{n}^{\circ} 4$.

ROSENN, K. S.; DOWNES, R. 2000. Corrupção e reforma política no Brasil: o impacto do impeachment de Collor. Rio de Janeiro: FGV Editora.

SALLUM JR., B. 1994. "Transição política e crise de Estado”. Revista Lua Nova, n $^{\circ}$ 32, São Paulo: Cedec.

1995. Crise e transição política: da distensão à Nova República. Tese de Livre-Docência, FFLCH, USP.

. 1999. "O Brasil sob Cardoso: neoliberalismo e desenvolvimentis-

mo”. Tempo Social - Revista de Sociologia da USP, vol. 11, nº 2.

. 2003. "Metamorfoses do Estado Brasileiro no Final do Século

XX”. Revista Brasileira de Ciências Sociais, vol. 18, ${ }^{\circ}$ 52, São Paulo: Scielo.

.; KUGELMAS, E. 1993. "O leviatã acorrentado: a crise brasileira dos anos 80”. In: SOLA, L. (org.). Estado, mercado e democracia: política e economia comparadas. Rio de Janeiro: Paz e Terra.

SERRA, J. 1995. Reforma política no Brasil. São Paulo: Siciliano.

SKIDMORE, T. 1988. Brasil: de Castelo a Tancredo. Rio de Janeiro: Paz e Terra. 
. 2000. "A queda de Collor: uma perspectiva histórica". In: ROSENN, K. S.; DOWNES, R. Corrupção e reforma política no Brasil: o impacto do impeachment de Collor. Rio de Janeiro: FGV Editora.

SOLA, L. (org.). 1993. Estado, mercado e democracia: política e economia comparadas. Rio de Janeiro: Paz e Terra.

SOUZA, C. 2003. "Políticas públicas e orçamento público: conflitos e cooperação”. In: BENEVIDES, M. V., VANNUCHI, P.; KERCHE, F. Reforma política e cidadania. São Paulo: Fundação Perseu Abramo.

VALLADARES, L.; COELHO, M. 1995. Governabilidade e pobreza no Brasil. Rio de Janeiro: Civilização Brasileira.

VELASCO e CRUZ, S. C. 1997. Estado e economia em tempo de crise: política industrial e transição política nos anos 80. Rio de Janeiro: Relume Dumará/Campinas, SP: Ed. Unicamp.

WEFFORT, F. C. 1992. Qual democracia? São Paulo: Cia das Letras. 


\section{POLÍTICAS PÚBLICAS E ESTADO: O PLANO REAL}

MARCUS IANONI

O artigo aborda o papel do Plano Real na reconstrução do Estado brasileiro. A tese principal é que havia então uma crise sociopolítica do Estado (crise de hegemonia do pacto de dominação) e não apenas uma crise de governabilidade, segundo avaliava o pensamento predominante na literatura da ciência política brasileira à época. O sucesso do Plano Real explica-se por ele ter sido o carro-chefe de um programa de mudança que foi conduzido num processo de repactuação sociopolítica liberal do poder de Estado. O envolvimento da esfera políticoinstitucional nesse processo de mudança logrou a superação da crise de governabilidade existente até 1993. No período histórico aberto pelo Plano Real, até o principal partido de esquerda, o PT, foi induzido a aderir, ao seu modo, desde a campanha eleitoral de 2002, a uma política macroeconômica liberal, embora o governo de coalizão de Lula esteja executando também políticas contra-hegemônicas. A análise identifica a origem e os determinantes da crise e algumas conjunturas de seu processo, com ênfase no governo Itamar Franco. O argumento mostra a importância da liderança política de Fernando Henrique Cardoso no processo do Plano Real, mas não adere a uma explicação voluntarista ou indeterminista, pois insere as ações dos sujeitos nos constrangimentos estruturais.

Palavras-chave: Plano Real; Políticas públicas; Estado desenvolvimentista; Crise de Estado; Hegemonia; Pacto de dominação; Neoliberalismo. 